\title{
Law, governance, and finance: introduction to the Theory and Society special issue
}

\section{Bruce G. Carruthers ${ }^{1}$}

Published online: 6 March 2020

(C) Springer Nature B.V. 2020

\begin{abstract}
After decades of deregulation and innovation, contemporary financial markets remain firmly anchored in law and legal institutions. The idea that private financial actors simply want to escape government oversight and regulation is simplistic as private interests find the coercive powers of the state too useful to forgo. Instead, such actors engage law selectively to create a more certain environment for themselves and their profit-seeking activities. Contract law adds certainty to financial transactions; law shapes how financial actors use information and exploit information technology; law constitutes financial values; and law allows financial institutions to be turned into assets. Law's application is shaped by changing conceptions of risk, as well as by new business models for financial institutions.
\end{abstract}

Keywords Bankgovernance Finance $\cdot$ Financial information · Financialization · Financial law $\cdot$ Regulation

The days of "3-6-3" banking are long gone: no more "borrow at 3\%, lend at 6\%, and be on the golf course by 3 pm" (Walter 2006). Instead of old-fashioned, predictable, relationship-based financial intermediation performed by national banks, what has emerged is a highly complex and dynamic financial system that spans the globe, is prone to instability, consists of banks, quasi-banks, shadow-banks, and a host of other institutions, and which tests the ability of national and international regulators to keep it all on an even keel. Innovation and deregulation have spawned new types of financial institutions transacting in innovative financial products and interacting with each other in novel ways. Quantitative finance has invented sophisticated tools for valuation, arbitrage, and risk management, and changes in information technology have greatly expanded the ability of market participants to accumulate, analyze, and exploit huge

Bruce G. Carruthers

b-carruthers@northwestern.edu

1 Department of Sociology, Northwestern University, 1810 Chicago Avenue, Evanston, IL 60208-1330, USA 
amounts of data. Algorithms now drive a substantial proportion of activity on equities markets, and the speed of transactions has increased by so many orders of magnitude that "latency arbitrage" has become a deliberate trading strategy (Pardo-Guerra 2019, p. 252).

The term "financialization" denotes the growing importance of financial institutions, activities, and relationships, for individuals, households, and firms (Krippner 2011, pp. 27-57). Many have noted, for example, that over the past several decades households have become increasingly leveraged, assuming substantial debts in order to maintain consumption, manage instabilities in earnings, or make investments in housing and education (e.g., Zinman 2015), although there are important cross-national variations in this process (Lazarus and Lacan 2018). Instead of having just a savings and a checking account, the average individual typically draws on a broader set of financial services from more than just banks, and they utilize various bank accounts, alternative savings vehicles, insurance, pension funds, credit cards, mobile money, and other payment systems (Fligstein and Goldstein 2015). More than ever before, the life chances of ordinary people depend on their access to the financial system and on their level of "financial literacy" (Maman and Rosenhek 2019), even as some remain largely excluded. In low-income countries, strategies of "financial inclusion" try to provide more people with financial services with the expectation that their lives will be improved (Beck and Demirgüç-Kunt 2008; Duncombe 2012). Similarly, non-financial firms have become more sophisticated in managing their own financial relationships, increasingly relying on a specialist CFO (chief financial officer) to supervise corporate cash flows, to enact tax strategies, to use derivatives to hedge various risks, and to find new ways to finance operations and rely less on traditional bank loans (Davis 2009; Mizruchi et al. 2006; Zorn 2004). Non-financial firms increasingly hold financial assets on their balance sheets. Financialization also possesses a cognitive or perceptual component as it involves a change in how actors assess and manage risks and uncertainties: assets are treated as largely fungible, and reductive "bottom lines" serve as criteria for evaluation (Besedovsky 2018).

Contemporary financial markets are complex and dynamic, and they generate a multitude of unintended consequences. They are full of surprises, to be sure, but they are not chaotic. Their order derives from market governance and possesses visible lineaments. It is an emergent order resulting from legal and institutional features that organize how contemporary markets work and that set the terms within which profitseeking firms and individual households operate. This set of features largely results from a mixture of historical contingencies, path dependencies, political interests, and institutional legacies: it is much more of a loose collection than a coherent system with a unitary architecture. It certainly is not a particularly efficient arrangement. For example, contemporary financial markets face the problem of legal pluralism: financial transactions often cross political borders and are subject to multiple and often inconsistent legal rules. How to resolve the legal contradictions that invariably arise? What jurisdiction governs a financial transaction involving parties in six countries? Sometimes public regulatory agencies try to coordinate among themselves through international organizations in order to harmonize their rules (e.g., IOSCO, the International Organization of Securities Commissions) but even within single national jurisdictions, like the United States, financial activities are subject to a patchwork of overlapping federal and state regulatory bodies, established at different times and for different 
purposes: there is no single integrated framework that encompasses all regulatory activities. And private organizations also set standards for how financial markets operate, with significant implications for political accountability: witness, for example, the importance of ISDA (the International Swaps and Derivatives Association) within the over-the-counter (OTC) derivatives market. This organization is dominated by the largest dealer banks, a financial "who's who." The current financial order has both public and private sources, and these often conflict with each other.

\section{Law and predictability in finance}

It seems natural to put financialization into the larger context of a neo-liberal ascendancy that includes deregulation, market innovation, the shrinking role of the state, the shift of risks to households, and the resurgence of laissez-faire approaches. Together, all seem to help explain the growing importance of financial markets. The articles in this issue, however, show that such a perspective is much too incomplete. Despite the rise of private power and decline of public power, in fact financial market actors continue to anchor their rules and institutions in public law, and they repeatedly seek the authority of the state to undergird and privilege their private arrangements. How they engage public power has shifted in significant ways, of course, but the nation-state has not disappeared or become irrelevant. Self-regulating markets are not part of a state-ofnature into which governments sometimes interfere. In reality, markets always depend on public power.

Financial obligations involve claims over current and future cash flows, either as a proportion of an underlying sum or underlying asset (as with bonds and loans, or derivatives) or as a varying residual amount that remains after other obligations have been met (e.g., dividends and retained earnings). Sometimes one cash flow has been exchanged for another, as in a currency or interest rate swap. Such claims can be contingent or not, but their intangibility makes legal enforcement especially critical: there is no physical thing to possess. Financial claims can be laid out in relatively simple agreements (e.g., loans and promissory notes) or in more complicated contractual arrangements (e.g., bespoke OTC financial derivatives). In situations where there are multiple competing claimants, priority rules sort out whose claims have seniority, and which therefore are satisfied first. Seniority has a large impact on their value.

Today, claims are overwhelmingly embodied in contractual commitments made by the involved parties, ${ }^{1}$ and much depends on the credibility of their promises. A loan, which is a relatively simple financial relationship, presupposes a key question: how much does the creditor trust the debtor? The answer will determine the terms of the loan (interest rate, maturity, amount, seniority, security), and even whether the debtor can borrow at all, and it is an answer that depends on information. Similarly, in newer financial transactions like currency and interest rate swaps, financial counterparties assess each other, judging whether the other side can deliver in the future what they

\footnotetext{
${ }^{1}$ I set aside the case of informal financial claims and transactions that forgo use of contracts (Macaulay 1963). Before the development of modern contract law, informal claims were common, and they remain important in specific situations like rotating credit associations. However, most of the contemporary financial system operates on the basis of formalized claims and obligations.
} 
promise today. They often rely on third parties (e.g., rating agencies like Moody's) to measure credit risk, and insist on collateral to protect themselves from that risk (Gregory 2010, p. 25). The value of collateral is itself measured with the help of third parties, and its inclusion in a financial transaction reflects the real possibility that someone will fail to keep their promises. In some instances, parties mitigate credit risk by purchasing credit insurance. In others, those risks can be hedged using financial derivatives like credit default swaps (which again depend on third parties to determine the occurrence of key triggering events). Furthermore, the terms of financial contracts are often set using private benchmark values: until the recent scandal, many loans around the world were priced on the basis of LIBOR (the London Interbank Offered Rate), and as LIBOR changed so did the price of credit (Schrimpf and Suchko 2019). In many different ways, flows of information from multiple sources enter into and shape financial obligations. But that information becomes relevant in the context of enforceable contracts and collateral.

Much of modern finance depends on the relationship between financial institutions and law. This connection is strong enough that Katharina Pistor (2019) coined the term "code of capital," to refer to how assets become legally "encoded" into capital. Her contribution to this volume elaborates on that fundamental connection and underscores law's constitutive role, and she offers a broad framework for analysis. Modern finance relies heavily on contract law and on the assurance that private agreements will be legally enforced in a predictable manner. It is subject to statutory law and public regulation. And the legal institution of private property undergirds the possession of economic value in the form of intangible financial assets. In a famous analysis, Max Weber underscored the importance of legal predictability for modern capitalist economies, and his insight continues to be highly relevant today. Predictable law is a prerequisite for modern capitalism (Weber 1981). Contracting parties will want to be certain ex ante about the legal meaning and implications of the specific provisions they include in their contracts, and so they peg their private expectations and arrangements to law backed by the coercive power of the state. They will want to know how regulators will apply legal rules to their market activities. They will also want to be sure who has title over an asset, and more generally that property rights are secure and freely transferable. In other words, financial market participants do not like legal surprises.

For financial contracts, some measure of certainty can be achieved through use of standardized language and boilerplate (Radin 2006; Kahan and Klausner 1997). In principle, each contract is unique to the circumstances and intentions of the two parties. However most contracts are not written de novo, but rather are constructed out of preexisting legal building blocks (Davis 2006; Suchman 2003). Using terms, provisions, and clauses whose pragmatic meaning has been settled through prior use in a specific legal jurisdiction, the parties writing a contract build their legal arrangement out of standardized elements. Some organizations deliberately create such boilerplate language for use in a particular area of finance, and they even create model laws for jurisdictions to adopt (e.g., ISDA's model netting rules for financial derivatives, see Flanagan 2001). Through choice-of-law provisions, contracts can mitigate the problem of legal pluralism by stating which specific jurisdiction will govern the terms of that contract: even if the actual transaction spans four continents, or involves intangible assets with no physical location, parties can agree that New York state law will be used 
to interpret and enforce the contract. ${ }^{2}$ Conveniently, this avoids the problem of how to harmonize laws.

In the ideal, contracts are freely negotiated on a bilateral basis, but particularly in the case of consumer finance, they are effectively written by one side and presented to the other side on a take-it-or-leave-it basis (Marotta-Wurgler and Taylor 2013). The consumer can enter into the transaction, on the terms given, or not. These are known as "contracts of adhesion" or "standard form contracts" and most individuals simply accept the terms as is. Credit card agreements, for example, are written by deeply experienced lawyers working for the supply side of the market. Since consumers often do not read these contracts (unsurprisingly, given their burdensome length and heavy reliance on highly technical language), legal surprises are more likely to plague consumers rather than those on the other side of the transaction.

\section{Finance and information}

Another aspect of uncertainty is reflected in the distinction between informationsensitive and information-insensitive assets (Gorton et al. 2012). The former are assets whose perceived value depends on certain kinds of information. Such information is therefore useful and those who acquire it will adjust asset values depending upon what they learn. By contrast, what people know has little effect on the value of informationinsensitive assets, and so there is little incentive to gather information. As an example, compare two situations involving payment in an exchange: in one, party A pays for goods with a promissory note; in the other, party B pays for goods with cash. In the first situation, sellers of goods might acquire useful information about the value of the promissory note by learning the identity of the payer A: are they trustworthy? Do they have a good record of keeping their promises? Are they creditworthy? As an asset, that promissory note is information sensitive. In the second situation, however, acquiring information about the identity and track record of payer B implies little about the value of their payment because legal tender is legal tender, and its value does not depend on who makes the payment. The fungibility of cash ensures that $\$ 20$ paid by an impecunious liar is as effective as $\$ 20$ paid by a billionaire of great integrity in satisfying an obligation worth $\$ 20$. Clearly, transactions involving information-insensitive assets involve less uncertainty than others. Yet this meaningful difference is not an intrinsic one, for it depends on the institutional nexus in which those assets are normally embedded, as Pistor points out in her article. Setting standards for financial assets like home mortgages, for example, helps to make them less information sensitive (Carruthers and Stinchcombe 1999). Most obviously, the ability of legal tender to function as a means of payment depends on its status, bestowed by government, and not on any inherent characteristics. Without such status, cash is no more than a piece of paper.

Ordinarily, market liquidity is higher for information-insensitive assets, in part because potential buyers and sellers need not have access to special information in order to value the asset, and so the market is more inclusive. Trading in such assets is less subject to information asymmetries. But situations can arise where the status of

\footnotetext{
${ }^{2}$ New York and London are the two most common options selected in choice-of-law clauses within financial contracts.
} 
information-insensitive assets is dramatically and catastrophically transformed. During the global financial crisis of 2008, for instance, assets that were ordinarily highly liquid suddenly became illiquid, and information insensitivity suddenly lost its former advantage. Instead, assets whose values were previously unquestionable became hard to sell at anything but "fire sale" prices, if they could be sold at all. The rapid spread of illiquidity was enormously destabilizing. US bank assets plunged in value so quickly that banks pressured regulators to release them from the strictures of mark-to-market accounting: basically, banks did not want to acknowledge how much declining market prices had reduced what their assets were worth (Carruthers 2017). Informationinsensitivity can be ephemeral.

Many financial assets remain sensitive to information. Indeed, that connection is central to the efficient markets hypothesis, which posits that in efficient markets prices fully reflect all available information (Fama 1970). But whether or not one subscribes to that hypothesis, it is clear that information, in respect to its accuracy, reliability, credibility, and availability, plays a critical role in financial markets. Traditional bank loans were "information sensitive" and generally hard to sell: banks possessed private information about their borrowers and could not readily convey all they knew to a potential loan buyer. Some of that information was "hard" (i.e., easily formalized and distributed) and some of it was "soft" (i.e., tacit and not easily formalized), to use Petersen and Rajan's (2002) distinction. So bank loans stayed on the books until maturity. However, loan securitization offered a way to allow banks to move loans off their balance sheets (Fabozzi and Kothari 2008, pp. 215-216). By bundling conforming loans together and issuing new securities backed by those assets, and furthermore by ordering those new securities into different tranches that varied by seniority, securitizers could merge idiosyncratic and information-sensitive assets into larger pools whose relevant statistical properties (e.g., expected default rates) could be estimated and priced. As Kim Pernell indicates later in this issue, securitizations were widely adopted by financial institutions as they moved away from traditional banking.

Information certainly enters into the traditional model of the bank as a depository institution, with its familiar "maturity mismatch" between short-term liabilities and long-term assets. In the "3-6-3" world, banks depended on retail depositors for much of their funding, promising them "on demand" funds that could be withdrawn at any point. Before deposit insurance, depositors had to worry about the financial status of their bank, because if the bank were to become insolvent, they would likely lose their money. Whether justified or not, the anticipation of insolvency set off bank runs, where depositors tried to make withdrawals en masse and the bank was quickly drained of all its cash because it could not sell its long-term assets fast enough to meet all obligations. Federal deposit insurance through FDIC, a New Deal creation, effectively made deposits more "information insensitive" and very much reduced the danger of a bank run. Although retail demand deposits are short-term in principle, in practice depositors who do not worry about bank runs kept their money in banks for long periods of time and so retail deposits provided a stable source of funds.

Today's banks fund themselves differently. To be sure, retail deposits continue to play an important role, but banks have increasingly turned to brokered deposits and "repo" as sources of funds. Repo involves very short-term repurchase agreements where one bank agrees to sell securities to another, and to repurchase them shortly, sometimes as soon as the next day. Repo acts very much like an overnight secured loan, 
and the difference between the sale and repurchase prices effectively constitutes the interest on the loan. The securities are usually among the most highly rated, liquid and safe financial assets, and they effectively constitute the collateral on the loan. However, repo does not involve retail customers but rather is transacted between large, sophisticated financial institutions. Leon Wansleben points out that because repo consists of the purchase and repurchase of information-insensitive assets, banks routinely used it to fund their activities, notwithstanding the extremely short maturity. Yet during a financial crisis, many information-insensitive assets suddenly become very sensitive, and then banks can no longer depend on repo. The sudden collapse of repo markets can push banks into insolvency. Wansleben also reveals the private origins of the institutional apparatus supporting repo, but observes, consistent with Pistor's argument, that this apparatus depends on public law in several crucial ways.

Markets that rely on information will necessarily be affected by changes in information technology and other developments that make information cheaper to acquire and process. The success of the famous "stock ticker" embodies the historical significance of technology in distributing financial information and creating a broader community of investors (Preda 2009). Financial exchanges that used to operate on an "open outcry" system, where individuals physically stood close together on a trading floor and transacted with each other through shouts and hand signals, now operate electronically, their trading floors are empty spaces and transactions are executed automatically through a computerized order matching system. Outside the exchanges, developments in information technology have greatly expanded the ability of financial institutions to gather and analyze large amounts of data, to pursue more sophisticated risk management and hedging strategies, and to make financial decisions using computer algorithms rather than human judgement. For example, on-line loans can be obtained in only seconds thanks to the fact that multi-stage financial decisions (loan selection, application, prequalification, underwriting, and closing) have been automated (Hess and Kemerer 1994). As Juan Pablo Pardo-Guerra points out in his contribution here, despite the self-evident importance of technology and technological change, US financial market regulators have mostly ignored it. This is an intriguing mystery.

Some sources of non-price information have become highly institutionalized in financial markets and play a role in governance. Measures of credit risk, or creditworthiness, enable lenders and firms to decide whether to enter into a financial transaction with a counterparty and on what terms. All of these are privately produced by for-profit businesses. Bond rating agencies sold information to investors about the risks associated with long-term debt starting in the early twentieth-century (Cantor and Packer 1994; Flandreau and Sławatyniec 2013). Before that, starting in the middle of the nineteenth-century, mercantile agencies were providing information about the credit risks associated with small businesses and trade credit (Cohen and Carruthers 2014; Flandreau and Mesevage 2014). And starting in the middle of the twentieth-century, credit rating agencies constructed scores measuring the creditworthiness of individual consumers (Fourcade and Healy 2013; Poon 2007). In all three cases, credit information has been used in new ways that give it additional significance. Bond ratings, for example, were incorporated into national and later international bank regulations starting in the 1930s. They are now critical to the production of asset-backed securities and other forms of structured finance, and they are routinely used in contracts for OTC derivatives. Access to consumer credit in the United States depends on a person's 
individual FICO score and on credit information supplied by three major rating agencies (TransUnion, Experian, and Equifax). Now, however, such scores are used by employers, landlords, insurance companies, and others (Kiviat 2019; O'Brien and Kiviat 2018; Rona-Tas 2017), and they are being incorporated into various "big data" strategies (Hurley and Adebayo 2016). The legal status of credit score information was contested during the nineteenth-century, then settled, and following the Global Financial Crisis of 2008 has become an issue again (Gaillard and Waibel 2018). The shift from the "user pays" to the "issuer pays" business model partly accounts for this legal change. Early on rating agencies were sometimes sued by those who were rated on the grounds that when incorrect such ratings were defamatory. Firms given a low rating were denied access to credit, and sometimes they took the rating agency to court. Gradually, however, ratings were deemed to be "opinions" and therefore protected as a form of free speech: their accuracy became irrelevant. And very recently they were reclassified as a type of commercial speech without such protection. The legal status of information is shifting once again.

\section{Finance and regulation}

Market actors also worry about the uncertainties generated by regulatory oversight. Through many channels, regulatory rulings can have a huge impact on profits and market activity and regulatory discretion can be an unwelcome source of ex ante and ex post ambiguity. One obvious response is to gain some measure of control over the regulator. As many have noted, private businesses often try to "capture" regulatory agencies, or otherwise gain influence through a variety of means (Stigler 1975). But they may also attempt simply to evade regulators, to stay out of their purview, and so escape oversight. Financial firms that undertake some bank-like activities are usually careful not to satisfy fully the formal definition of a bank because of the regulatory oversight that entails. Instead, they become part of the "shadow banking" system. Or firms create hybrid financial products that do not map easily into regulatory categories. The basic insight of "capture theory," that relations between financial firms and financial regulators are bilateral, is given rich elaboration in the articles in this issue. But rather than using captured regulators simply to effect a static market with limited entry and high prices, the financial industry has used its influence over regulatory actions to allow innovation and risk-taking, and to give legal force to some of their preferred arrangements. When ISDA's model netting rules become enshrined in national bankruptcy statutes, derivatives counterparties suddenly enjoyed a legal superpriority when firms failed and their assets were given up to creditors (Roe 2011). Furthermore, regulators face a dilemma when dealing with the very largest and systemically-important financial institutions, whose too-big-to-fail status can protect them from the application of the bankruptcy or insolvency rules that ordinarily impose market discipline (Woll 2014). The likelihood of a bailout mitigates market uncertainty for those large enough to be so privileged.

Private financial groups may try to capture their regulators, but they do not always succeed. One feature standing in the way of simple capture is the autonomous professional expertise of regulatory personnel. Regulators are less likely to comply with external political pressures if their standing as professionals depends on expert knowledge that is independent from those pressures, and if that knowledge informs 
their decisions as regulators. In other words, the ideas that regulators embrace can make a big difference. Certainly, this is the point of Erin Lockwood's article in this issue. She argues that changing conceptions of risk and innovation played a role in the decision not to regulate derivatives markets. This choice, or more accurately series of choices, unfolded in the United States during the 1990s and culminated in the 2000 Commodity Futures Modernization Act. She makes the important point that for a market to be unregulated is not a default state-of-nature but rather is a deliberate outcome. Furthermore, ideational absences can be as telling as inclusions. Relying on some innovative computational text-analytic methods, Pardo-Guerra also discusses how SEC regulators thought about the markets they oversaw, and despite being well aware of the importance of technological change, they mostly said little about it. Despite clear evidence that their understanding of markets changed over the decades, and that they increasingly emphasized information, accounting standards, disclosure, and transparency in markets, information technology per se remained outside their purview. His analysis reveals a broader fact about regulators, namely that they are not always trying to build expansive empires. Sometimes, by "black-boxing" an issue, they deliberately forgo jurisdiction and the responsibilities that come with it.

The tensions between public and private power, the ways in which private parties selectively engage with formal law, and how these affect financial innovation, are well illustrated in the recent case of cyber-currencies and e-money. Money is traditionally the domain of sovereign power. National government reserves for itself the right to create a national currency, and the latter is one of the hallmarks of an independent nation state. Market actors value that special status, for in a financial crisis all join in a "flight to quality" involving conversion of their assets into legal tender. States protect that special status by actively suppressing rival domestic currencies as fakes and counterfeits. Indeed, the prosecution of international counterfeiting laid the basis for cooperative law enforcement through Interpol (Carruthers and Arslan 2019, pp. 527528). And yet, through the development of new payment systems and various types of cyber-currency, private parties are again creating alternative media of exchange that, they hope, will be widely used in market transactions. In some cases, these new media embody political hopes for a form of money free from any government control. Early promoters of bitcoin, for example, wanted to sever new money from political sovereignty and enact a type of cyber-anarchist vision (Lawrence and Mudge 2019; Pistor 2019 , p. 197). Now, it seems that while financial market incumbents may adopt bitcoin's distributed ledger system, because of its highly volatile value bitcoin itself will more likely function as a cyber-asset than a cyber-currency (HM Treasury 2018). In other developments, companies with massive user networks aim to capitalize on their social media platforms by adding new monetary and payment services. Among other things, this would allow private companies like Facebook (which is promoting its own cryptocurrency, Libra) to add massive amounts of financial data to all the other information they have about their users and create for themselves additional data streams to be monetized. However, since user networks cut across national borders, it is highly likely that payments would as well, and cross-border payments trigger various laws against money laundering and financing terrorism. As well, money creation by non-financial institutions threatens the traditional means through which central banks measure financial markets and enact monetary policy, and it may make the latter less effective. 


\section{Firms as financial assets}

Corporations, including financial institutions like banks, are themselves a form of legally-constituted private property, manifesting in clear relief the entanglement of private interests with public legal power. For publicly-traded firms, ownership interests depend on possession of company shares, and the extent of the interest depends on the proportion of outstanding shares that are held by an individual owner: holding over $50 \%$ gives someone majority ownership. When holdings are widely dispersed, a smaller percentage will confer effective control. ${ }^{3}$ These ownership interests are traded on stock exchanges and include financial rights (a claim to residual income via dividends, or to capital gains in the event of retained earnings) and control rights (the ability to vote in company elections, help select company directors, etc.). In an influential statement, Berle and Means (1932) argued that widely-held publicly-traded corporations were a new type of property, one where ownership and control had become separated from each other. Company shareholders had formal ownership rights, but actual control of the company was in the hands of the firm's top management.

For scholars interested in corporate governance, the divergence of interests between owners and management was an agency problem that required a solution. How can we be sure that the interests of agents (managers) would be aligned with those of principals (shareholders)? Agency theory (e.g., Jensen and Meckling 1976) was born of this problem, and in application it helped to generate a revolution in corporate governance and executive compensation (Murphy 2013, pp. 323-327). Compensation via bonuses, stock plans, and stock options were all intended to solve these agency problems. Furthermore, institutional investors like pension funds have become much more important as company owners than individual investors, and their ownership interests differ. Ownership, it turns out, is complicated. The articles by Kim Pernell and Stephen Nelson both explore the significance of corporate governance for the behavior of financial firms. Pernell argues that, in the United States, "shareholder value" policies motivated by agency theory were adopted about a decade later in the financial sector than in the non-financial corporate sector, but their adoption encouraged US banks to engage in riskier behavior that led to greater overall instability. Innovation produced new financial products and activities, but it was the change in governance that encouraged banks to embrace these riskier innovations. Changes in corporate governance, in other words, changed individual firm behavior but then had adverse consequences for the overall financial system. Nelson offers a comparative perspective, showing that the nationality of ownership matters and, in particular, that foreignowned banks behaved differently than domestically-owned banks, even as they transmitted the effects of the 2008 financial crisis around the world. Globalization has, among other things, internationalized banking systems, and so foreign-owned banks have become a fact of life in many countries. According to his analysis, the particular combination of foreign and domestic ownership made a significant difference in how banks responded to the global financial crisis: by reducing their lending activity, foreign-owned banks worsened the effects of the crisis in Central and Eastern Europe, but not in Latin America. The difference, Nelson points out, lies in the level of financialization, and how far banks had departed from traditional banking models.

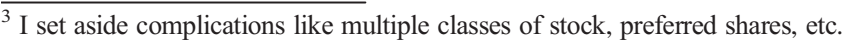




\section{Conclusion}

The articles in this issue shed new light on the governance of financial markets at the macro-level of laws, regulators, and financial institutions. In a highly financialized society, such governance has direct implications for the micro-level of households and individual consumers because such institutions remain a primary source of retail financial services and many individual liabilities are now grist for the securitization mill. Governance involves compliance with rules that frequently come from public regulators but also have private sources. Formal law remains a critical anchor for finance, for only through law can claims over intangible assets and cash flows be realized with certainty. The acid test comes during a crisis, when financial actors rush to convert their private claims into legal tender, the safest and most certain asset of all. Legal pluralism poses a challenge, but legal harmonization, the promulgation of model laws, or reliance on choice-of-law provisions, can help remedy the uncertainty. However, this does not mean that financial actors can simply evade or nullify whatever legal rules they dislike. Large polities, like the European Union, the United States, and increasingly China, have large internal markets and can use the lever of market access to impose their rules and regulations. A financial institution that does not comply with the EU's new Global Data Protection Regulation, for example, risks losing access to a very large market. The content of such rules depends on how regulators conceptualize risk and on the extent of their autonomy from political bosses.

The Global Financial Crisis of 2008 prompted much consideration of financial regulation and governance. The reigning presumption that private risk management performed by sophisticated and self-interested market actors would be sufficient to avoid systemic crises was decisively refuted by the events of that year. After decades of deregulation and re-regulation, public authorities were given new powers and expanded oversight. And there was some attempt to move away from an "entity-based" approach, which focused on the safety and solvency of individual financial institutions, to one that also considered the network connections among institutions and whether the entire financial system was itself stable. Yet the importance of private regulation continues, and much market governance still happens with little public oversight or input.

Law shapes the kinds of information that circulate through financial markets, starting with numerous disclosure requirements that mandate provision of certain kinds of accounts and performance measures. Many such requirements are set in pursuit of an ideal of transparent markets where prices are the best measure of value and where information asymmetries are mitigated if not entirely rebalanced. But law also shapes the status of information that is privately created and exploited, encumbering providers but also constraining users' ability to seek damages when information is inaccurate or misleading. As finance moves into an era of "big data," where individual consumer activity is tracked in real time at a granular level but on a mass scale, the legal status of personal information will be a key issue in shaping who can access and exploit such data. Innovations in information technology have created new possibilities, but privacy regulations, obligations in regard to cybersecurity, rules governing data ownership, anti-money laundering and anti-terrorism regulations, and older consumer protection and anti-discrimination measures constrain their exploitation.

Despite much innovation, banks remain key financial institutions. As financial actors, banks seek funding from new sources, and they earn profits in new ways, but 
they are still important for how financial markets operate. Their willingness to use repo for their financing requires a nimble balancing act that can quickly destabilize into a new type of bank run. And their shift away from the originate-to-hold to the originateto-distribute lending model marked the rise of securitization as a way to reduce regulatory capital and boost profits. It also moved banks away from relationship lending to a more transactional basis. In pursuing these new activities, however, banks have continued to build up their capabilities as "information machines" (Guinnane 2001). As corporations, banks are themselves financial assets that are subject to ownership and control. Institutional investors that press hard for short-term profits and buoyant share prices encourage greater risk taking by bank managers. And foreign owners may dictate policies that accommodate market conditions in their home country, but worsen matters for their subsidiary's host country. As powerful political actors, banks influence the regulators and legislators who ostensibly oversee them, and they certainly shape many private regulatory arrangements. Banks operate in a dynamic legal and institutional environment that they have helped to create, albeit with numerous unintended consequences, but it is a brave new world where "3-6-3" banking is a thing of the past.

Acknowledgments My thanks to Greta Krippner for her support of this special issue of Theory and Society and to Steve Nelson for helpful comments. Many of the articles were first presented at a conference held at Northwestern University in 2018 and financed by the Buffett Institute for Global Studies.

\section{References}

Beck, T., \& Demirgüç-Kunt, A. (2008). Access to finance: an unfinished agenda. World Bank Economic Review, 22(3), 383-396.

Berle, A. A., \& Means, G. C. (1932). The modern corporation and private property. New York: Harcourt, Brace and World.

Besedovsky, N. (2018). Financialization as calculative practice: the rise of structured finance and the cultural and calculative transformation of credit rating agencies. Socio-Economic Review, 16(1), 61-84.

Cantor, R., \& Packer, F. (1994). The credit rating industry. Federal Reserve Bank of New York Quarterly Review, (Summer/Fall), 1-26.

Carruthers, B. G. (2017). Financial decommodification: risk and the politics of valuation in U.S. banks. In E. J. Balleisen, L. S. Bennear, K. D. Krawiec, \& J. B. Wiener (Eds.), Policy shocks: recalibrating risk and regulation after oil spills, nuclear accidents, and financial crashes (p. 2017). New York: Cambridge University Press.

Carruthers, B. G., \& Arslan, M. (2019). Sovereignty, law, and money: new developments. Annual Review of Law and Social Science, 15, 521-538.

Carruthers, B. G., \& Stinchcombe, A. L. (1999). The social structure of liquidity: flexibility in markets and states. Theory and Society, 28(3), 353-382.

Cohen, B., \& Carruthers, B. G. (2014). The risk of rating: negotiating trust and responsibility in 19th century credit information. Sociétés Contemporaines, 93, 39-66.

Davis, K. E. (2006). The role of nonprofits in the production of boilerplate. Michigan Law Review, 104(5), $1075-1103$.

Davis, G. F. (2009). Managed by the markets: how finance reshaped America. New York: Oxford University Press.

Duncombe, R. (2012). An evidence-based framework for assessing the potential of mobile finance in subSaharan Africa. Journal of Modern African Studies, 50(3), 369-395.

Fabozzi, F. J., \& Kothari, V. (2008). Introduction to securitization. New York: Wiley. 
Fama, E. F. (1970). Efficient capital markets: a review of theory and empirical work. Journal of Finance, 25(2), 383-417.

Flanagan, S. M. (2001). The rise of a trade association: group interactions within the international swaps and derivatives association. Harvard Negotiation Law Review, 6, 211-264.

Flandreau, M., \& Mesevage, G. G. (2014). The separation of information and lending and the rise of rating agencies in the USA (1841-1907). Scandinavian Economic History Review, 62(3), 213-242.

Flandreau, M., \& Sławatyniec, J. K. (2013). Understanding rating addiction: US courts and the origins of rating agencies' regulatory license (1900-1940). Financial History Review, 20(3), 237-257.

Fligstein, N., \& Goldstein, A. (2015). The emergence of a finance culture in American households, 19892007. Socio-Economic Review, 13(3), 575-601.

Fourcade, M., \& Healy, K. (2013). Classification situations: life-chances in the neoliberal era. Accounting, Organizations and Society, 38, 559-572.

Gaillard, N., \& Waibel, M. (2018). The Icarus syndrome: how credit rating agencies lost their quasi immunity. SMU Law Review, 71(4), 1077-1116.

Gorton, G., Lewellen, S., \& Metrick, A. (2012). The safe-asset share. American Economic Review, 102(3), $101-106$.

Gregory, J. (2010). Counterparty credit risk: the new challenge for global financial markets. New York: Wiley.

Guinnane, T. W. (2001). Cooperatives as information machines: German rural credit cooperatives, 1883-1914. Journal of Economic History, 61(2), 366-389.

Hess, C. M., \& Kemerer, C. F. (1994). Computerized loan origination systems: an industry case study of the electronic markets hypothesis. MIS Quarterly, 18(3), 251-275.

Hurley, M., \& Adebayo, J. (2016). Credit scoring in the era of big data. Yale Journal of Law and Technology, $18,148-216$.

Jensen, M. C., \& Meckling, W. H. (1976). Theory of the firm: managerial behavior, agency costs and ownership structure. Journal of Financial Economics, 3, 305-360.

Kahan, M., \& Klausner, M. (1997). Standardization and innovation in corporate contracting (or "the economics of boilerplate"). Virginia Law Review, 83(4), 713-770.

Kiviat, B. (2019). The art of deciding with data: evidence from how employers translate credit reports into hiring decisions. Socio-Economic Review, 17(2), 283-309.

Krippner, G. R. (2011). Capitalizing on crisis: the political origins of the rise of finance. Cambridge: Harvard University Press.

Lawrence, C. J., \& Mudge, S. L. (2019). Movement to market, currency to property: the rise and fall of Bitcoin as an anti-state movement, 2009-2014. Socio-Economic Review, 17(1), 109-134.

Lazarus, J., \& Lacan, L. (2018). Toward a relational sociology of credit: an exploration of the French literature. Socio-Economic Review, 1-23. https://doi.org/10.1093/ser/mwy006.

Macaulay, S. (1963). Non-contractual relations in business: a preliminary study. American Sociological Review, 28(1), 55-67.

Maman, D., \& Rosenhek, Z. (2019). Responsibility, planning and risk management: moralizing everyday finance through financial education. British Journal of Sociology, 70(5), 1996-2019.

Marotta-Wurgler, F., \& Taylor, R. (2013). Set in stone? Change and innovation in consumer standard-form contracts. New York University Law Review, 88, 240-285.

Mizruchi, M. S., Stearns, L. B., \& Marquis, C. (2006). The conditional nature of embeddedness: a study of borrowing by large U.S. firms, 1973-1994. American Sociological Review, 71(2), 310-333.

Murphy, K. J. (2013). Executive compensation: where we are, and how we got there. In G. M. Constantinides, M. Harris, \& R. M. Stulz (Eds.), Chapter 4 in handbook of the economics of finance, volume 2, part A (pp. 211-356). Oxford: Elsevier.

O’Brien, R. L., \& Kiviat, B. (2018). Disparate impact? Race, sex, and credit reports in hiring. Socius, 4, 1-20.

Pardo-Guerra, J. P. (2019). Automating finance: infrastructures, engineers, and the making of electronic markets. Cambridge: Cambridge University Press.

Petersen, M. A., \& Rajan, R. G. (2002). Does distance still matter? The information revolution in small business lending. Journal of Finance, 57(6), 2533-2570.

Pistor, K. (2019). The code of capital: how the law creates wealth and inequality. Princeton: Princeton University Press.

Poon, M. (2007). Scorecards as devices for consumer credit: The case of fair, Isaac \& Company Incorporated. The Sociological Review, 55(2), 284-306.

Preda, A. (2009). Framing finance: the boundaries of markets and modern capitalism. Chicago: University of Chicago Press. 
Radin, M. J. (2006). Boilerplate today: the rise of modularity and the waning of consent. Michigan Law Review, 104(5), 1223-1234.

Roe, M. J. (2011). The derivatives Market's payment priorities as financial crisis accelerator. Stanford Law Review, 63, 539-590.

Rona-Tas, A. (2017). The off-label use of consumer credit ratings. Historical Social Research, 42(1), 52-76.

Schrimpf, A., \& Suchko, V. (2019). Beyond LIBOR: a primer on the new reference rates. BIS Quarterly Review, (March), 29-52.

Stigler, G. J. (1975). The citizen and the state: essays on regulation. Chicago: University of Chicago Press.

Suchman, M. C. (2003). The contract as social artifact. Law and Society Review, 37(1), 91-142.

Treasury, H. M. (2018). Cryptoassets taskforce: final report. London: Her Majesty's Treasury.

Walter, J. R. (2006). The 3-6-3 rule: an urban myth? Federal Reserve Bank of Richmond Economic Quarterly, 92(1), 51-78.

Weber, M. (1981). General economic history. New Brunswick: Transaction Books.

Woll, C. (2014). The power of inaction: bank bailouts in comparison. Ithaca: Cornell University Press.

Zinman, J. (2015). Household debt: facts, puzzles, theories, and policies. Annual Review of Economics, 7 , $251-276$.

Zorn, D. M. (2004). Here a chief, there a chief: the rise of the CFO in the American firm. American Sociological Review, 69(3), 345-364.

Publisher's note Springer Nature remains neutral with regard to jurisdictional claims in published maps and institutional affiliations.

Bruce G. Carruthers is the John D. MacArthur Professor of Sociology at Northwestern University and Nonresident long-term Fellow at the Swedish Collegium for Advanced Study. He is currently finishing a book on the historical sociology of credit and credit decision-making in the United States in the nineteenth and twentieth centuries He also works on the topics of corporate social responsibility and taxation, and organizational changes in US museums. 